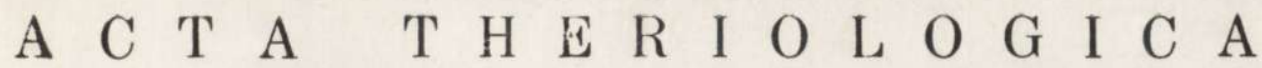 \\ VOL. X, 13: 20̄9-214. \\ BIAEOWIEŻA \\ 30.IX.1965
}

\author{
Zofia GĘBCZYŃSKA \& Marek GĘ BCZYNSKI
}

\section{Oxygen Consumption in Two Species of Water-shrews}

\author{
[With 2 Figs. \& 2 Tables]
}

\begin{abstract}
The amount of oxygen consumed over a 24-hour period by Neomys anomalus does not differ from the average daily metabolic rate of Neomys fodiens. The metabolism of water-shrews is approximately $22 \%$ higher than that of rodents. The daily activity pattern of $N$. anomalus, however, differs from that in $N$. fodiens. There are also seasonal variations in metabolism and in the type of the daily activity pattern of $N$. fodiens.
\end{abstract}

\section{INTRODUCTION}

The European water-shrew, Neomys fodiens (P e n n a n t, 1771), is a species little known from the physiological aspect, while there is a complete lack of data of this kind on the Mediterranean water-shrew, Neomys anomalus C a b r e r a , 1907. General information on the quality and amount of food and the daily activity of the European water-shrew were given by T u pi k ova (1949), who maintains that $N$. fodiens, like shrews, is distinguished by a high metabolic rate. D e h nel (1951) also assumes, judging by his knowledge of the biology of the postnatal development of species of the genus Sorex and Neomys, that the representatives of these genera are distinguished by a high metabolic level. Hawkins et al. (1960) and Hawkins \& Jewell (1962), on the other hand, demonstrated in their investigations that the metabolism of $N$. fodiens does not differ from that of the white mouse or harvest mouse, Micromys minutus ( $\mathrm{P}$ allas, 1771).

The scanty and ambigucus data on the metabolism of the European water-shrew and their absence in relation to the Mediterranean watershrew induced the authors of this paper to investigate these two species. Measurement was made of the oxygen consumption and daily activity pattern in the autumn of two species of water-shrews, and in the winter only of $N$. fodiens. 


\section{MATERIAL AND METHODS}

The animals were caught in the Białowieża National Park. Before the experiment was started the animals were kept for several weeks in wooden cages in the laboratory at a temperature of about $18^{\circ} \mathrm{C}$. Their food consisted of minced meat with the addition of vitamins and sprouting wheat. Daily runs of oxygen consumption were measured in the respirometer described by G ę b c z y ńs k i (1963), which was based on the principle of similar apparatus described by $\mathrm{Ka} \mathrm{labukhov}$ (1951) and $\mathrm{Skvartzov}$ (1957).

During the experiments the water-shrews were given water and food in the same quantities as in the laboratory. Chemical thermoregulation was investigated at temperatures of $10,15,20,30$ and $35^{\circ} \mathrm{C}$ in 11 chambers, in which the animals, confined in a small cage, were placed, but in this case no food or water was given, and measurements lasted from $35-45$ minutes.

\section{RESULTS AND DISCUSSION}

The mean daily oxygen consumption (average daily metabolic rate $=$ $A D M R$ ) in N. anomalus in the autumn is slightly higher than in N. fodiens (Tab. 1). This difference is, however, statistically non-significant and can be explained by the smaller body weight of $N$. anomalus. On the

Table 1.

Average daily metabolic rate and daily energetic requirements of $N$. anomalus and $N$. fodiens at a temperature of $20^{\circ} \mathrm{C}$.

\begin{tabular}{|l|c|c|c|c|}
\hline & $\mathrm{n}$ & $\begin{array}{c}\text { Mean body } \\
\text { weight in } \mathbf{g m}\end{array}$ & $\begin{array}{c}A D M R \\
\text { cc/gm hr }\end{array}$ & $\begin{array}{c}\text { Kg. cal./animal } \\
\text { day }\end{array}$ \\
\hline $\begin{array}{l}\text { N. anomalus, } \\
\text { October } \\
\begin{array}{l}N . \text { fodiens, } \\
\text { October }\end{array}\end{array}$ & 6 & 13.57 & 6.57 & 10275 \\
$\begin{array}{l}\text { N. fodiens, } \\
\text { January }\end{array}$ & 4 & 14.72 & 6.32 & 10715 \\
\hline
\end{tabular}

other hand $A D M R$ in the European water-shrew is significantly lower in the winter than in the spring (Tab. 1). Calculation was also made of the average daily energetic requirements for one animal. It was assumed that the oxygen caloric coefficient was $4.8 \mathrm{Kcal} / 1.1$. This requirement is only $4.1 \%$ lower in $N$. anomalus than in $N$. fodiens, whereas in the winter in $N$. fodiens the difference in comparison with the autumn is $13.2 \%$ (Tab. 1).

The chemical thermoregulation in $N$. anomalus and $N$. fodiens was measured, but only during the autumn. From 8-16 individuals of each 
species were used in different temperatures (Tab. 2). The level of oxygen consumption by $N$. anomalus is higher than in $N$. fodiens within limits of temperature of $10-30^{\circ} \mathrm{C}$, and almost equal at a temperature of $35^{\circ} \mathrm{C}$ (Fig. 1). The thermoneutral zone in both species is spread over a range within limits of approximately $25-30^{\circ} \mathrm{C}$.

\section{Table 2.}

Oxygen consumption in $N$. anomalus and $N$. fodiens at different temperatures. The number of individuals examined is given in brackets.

\begin{tabular}{|c|c|c|c|c|c|c|c|}
\hline \multicolumn{2}{|c|}{ Temperature in ${ }^{\circ} \mathrm{C}$} & $10^{\circ}$ & $15^{\circ}$ & $20^{\circ}$ & $25^{\circ}$ & $30^{\circ}$ & $35^{\circ}$. \\
\hline \multirow{2}{*}{ 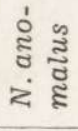 } & $R M R$ & 8.02 & 701 & 5.95 & 5.23 & 4.98 & 5.45 \\
\hline & $\begin{array}{l}\text { Mean body } \\
\text { weight in gm }\end{array}$ & $\begin{array}{l}12.89 \\
(8)\end{array}$ & $\begin{array}{c}12.94 \\
(8)\end{array}$ & $\begin{array}{r}13.21 \\
(.0)\end{array}$ & $\begin{array}{c}12.73 \\
(8)\end{array}$ & $\begin{array}{c}13.42 \\
(9)\end{array}$ & $\begin{array}{r}13.04 \\
(10)\end{array}$ \\
\hline \multirow{2}{*}{ 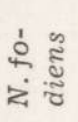 } & $R M R$ & 6.91 & 6.69 & 5.84 & 4.70 & 4.75 & 5.60 \\
\hline & $\begin{array}{l}\text { Mean body } \\
\text { weight in gm }\end{array}$ & $\begin{array}{c}14.78 \\
(12)\end{array}$ & $\begin{array}{c}14.05 \\
116)\end{array}$ & $\begin{array}{r}14.05 \\
(16)\end{array}$ & $\begin{array}{r}14.18 \\
(14)\end{array}$ & $\begin{array}{r}13.96 \\
(16)\end{array}$ & $\begin{array}{r}14.30 \\
(12)\end{array}$ \\
\hline
\end{tabular}

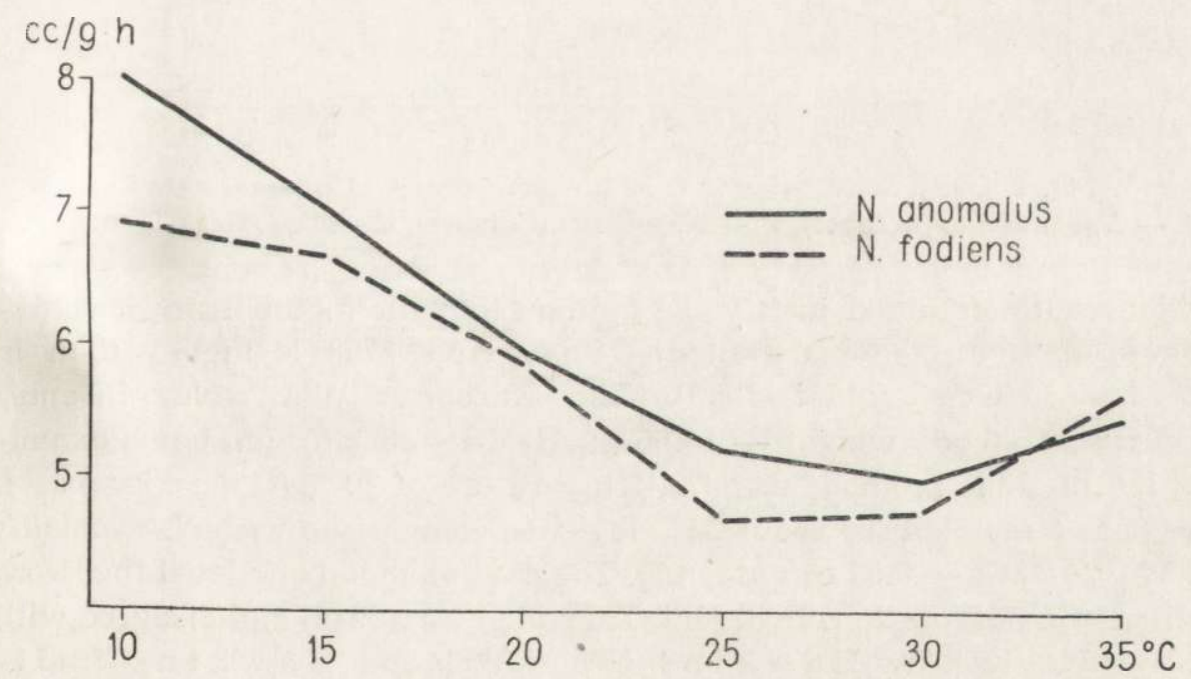

Fig. 1. Chemical thermoregulation in the autumn in the two species of water-shrews.

The daily activity pattern was established on the basis of the daily rhythm of oxygen consumption. Two-hour divisions were used, as they were in A s c h off's (1957) calculations. N. anomalus exhibits a simple bimodal daily activity pattern in the autumn (Fig. $2 \mathrm{~A}$ ). Both periods of heightened activity are distinctly separated from each other by an interval of about 12 hours. The first occurs at the end of the day, and the 
second at the end of the night. The difference between the maximum and minimum (amplitude) is considerable, being $2.82 \mathrm{cc} / \mathrm{gm}$ per hour. The daily acitivity pattern in $N$. fodiens in the autumn is of the same type as that in $N$. anomalus, yet differs considerably (Fig. 2 B). The periods of heightened activity are not so clearly separated and are less distinct. The interval between the peaks occurring during the night hours is 8 hours. The amplitude is more resticted than in $N$. anomalus, being $2.14 \mathrm{cc} / \mathrm{gm}$ hour. The daily activity pattern of $N$. fodiens is completely different in winter. It has only one peak, occurring during the final night hours (Fig. $2 \mathrm{C}$ ), and the amplitude here is the smallest (1.67 cc/gm hour).

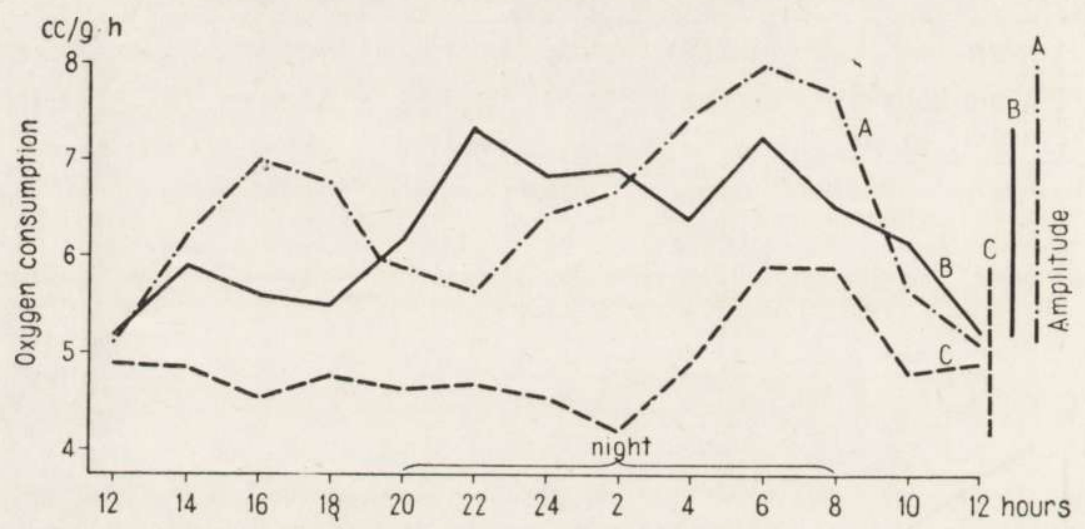

Fig. 2. Daily activity pattern of the two species of waier-shrews.

$\mathrm{A}-N$. anomalus (October), B $-N$. fodiens (October), C $-N$. fodiens (January).

The results obtained justify the opinion that the metabolism of watershrews, like that of Sorex araneus L inna e us, 1758 is higher than in rodents (Gębczyński, 1965). The European pine vole, Pitymys subterraneus (body weight $-13.66 \mathrm{~g} ; A D M R-5.58 \mathrm{cc} / \mathrm{gm}$ hour) examined by the same method, also at a temperature of $20^{\circ} \mathrm{C}$ (G ę b c z y ńs ki, 1964) has a metabolism about $22 \%$ lower in comparison with $N$. anomalus $(13.57 \mathrm{~g}, A D M R-6.57 \mathrm{cc} / \mathrm{gm}$ hour$)$. The data on metabolic level therefore confirm the observations made by $\mathrm{T} \mathrm{u} \mathrm{pi} \mathrm{k} \mathrm{ov} \mathrm{a} \mathrm{(1949)} \mathrm{and} \mathrm{disagree} \mathrm{with}$ the results given by $\mathrm{Hawk}$ ins et al. (1960) and $\mathrm{Hawkins}$ \& $\mathrm{J} \mathrm{e}-$ w e 11 (1962). Similarly the results of investigations of the rate of passage of foodstuffs through the alimentary tract of $N$. fodiens (Kos t e l e c k aMyrcha \& My rcha, 1964) form evidence of high metabolic rate. It is clear from the study referred to above that excretion of the main mass of food occurs rapidly, within two hours. The food requirements of the European water-shrew are large, over $18 \mathrm{~g}$ a day for animals with an average body weight of $15.6 \mathrm{~g}$ ( $\mathrm{T} \mathrm{u} \mathrm{p} \mathrm{i} \mathrm{k} \mathrm{ow} \mathrm{a,} \mathrm{1949).} \mathrm{This} \mathrm{most} \mathrm{certainly}$ is the cause of the great activity of $N$. fodiens. 
Despite the absence of a difference in metabolism, the daily activity pattern of $N$. anomalus differs from that of $N$. fodiens. The first of these species has a pattern with distnctly marked periods of increased activity before dusk and before dawn, while $N$. fodiens is more evenly active throughout the whole 24 hours, and its pattern differs in the winter from that in the autumn. The differences in the daily activity patterns of $N$. fodiens and $N$. anomalus are undoubtedly due to the different biology of these two species. The European water-shrew is larger, has venomous properties, and behaves aggressively (P u c e k, 1957); whereas the Mediterranean water-shrew is probably not venomous and there is some similarity between its biology and that of $S$. araneus. This is also borne out by the similarity of the daily activity pattern in the autumn of $N$. anomalus and $S$, araneus.

\section{REFERENCES}

1. A s c h off J., 1957: Aktivitätsmuster der Tagesperiodik. Naturwiss., 44: $361-367$.

2. Dehnel A., 1951: Studies on the genus Neomys K a u p. Ann. Univ. M. CurieSkłodowska, C, 5, 1: 1- -63 [In Polish with English and Russ. summ.].

3. G ębczyński M., 1963: Apparatus for daily measurements of oxygen consumption in small mammals. Bull. Acad. Pol. Sci., Cl. II, 11, 9: 433-436.

4. G ę b c z y ńs k i M., 1964: Effect of light and temperature on the 24-hour rhythm in Pitymys subterraneus (de S é 1. - L on g.). Acta theriol., 9, 9: 125-137.

5. Gębczy riski M., 1:365. Seasonal and age changes of the metabolism and activity of Sorex araneus Linnaeus, 1758. Acta theriol. (in print).

6. Hawkin s A. E. \& J e well P. A., 1962: Food consumption and energy requirements of captive British shrews and the mole. Proc. zool. Soc. Lond., 138, 1: $137-155$.

7. H awkins A. E., Jewell P. A. \& Tomlins on G., 1960: The metabolism of some British shrews. Proc. zool Soc. Lond., 135: 99-103.

8. K a la bukhov N.I., 1951: Metodika eksperimentalnyh issledovanij po ekologii nazemnyh pozvonočnyh. Izd. "Sov. nauka": 1-176. Moskva-Leningrad.

9. Kostelecka-Myrcha A. \& Myrcha A., 1964: Rate of passage of foodstuffs through the alimentary tract of Neomys fodiens ( $\mathrm{P}$ e n n a n t, 1771) under laboratory conditions. Acta theriol., 9, 20: 371-373.

10. Pucek M., 1957: Die toxische Wirkung der Glanduiae submaxillares bei Neomys fodiens fodiens S chre b. Bull. Acad. Pol. Sci., Cl. II, 5, 9: 301-306.

11. Skvortzov G. N.., 1957: Ulutšennyj metod opredelenija potreblenija kisloroda gryzunami i drugimi melkimi životnymi. Sb. "Gryzuny i borba s nimi", 5: $124-132$.

12. Tupikova N. V., 1949: Pitane i harakter sutočnoj aktivnosti zemleroek srednei polosy SSSR. Zool. Ż., 28, 6: $561-572$.

Polish Academy of Sciences,

Mammals Research Institute,

Riałowieża, woj. Białystok. 
Z.ofia GĘBCZYŃSKA \& Marek GĘBCZYŃSKI

\section{ZUŻYCIE TLENU U DWOCH GATUNKOW RZESORKOW}

\section{Streszczenie}

Jesienią zmierzono wielkość dobowego zużycia tlenu u rzęsorka rzeczka, Neomys fodiens i rzęsorka mniejszego, $N$, anomaius a w zimie tylko u rzęsorka rzeczka. Stwierdzono, że dobowe zużycie tlenu $N$. anomalus różni się nieistotnie od tej wartości dla $N$. fodiens (Tabela 1). Natomiast dobowe zużycie $\mathrm{O}_{2}$ rzęsorka rzeczka w zimie jest istotnie niższe niż jesienią (Tabela 1).

Na podstawie uzyskanych wyników można sądzić, że metabolizm rzęsorków jest wyższy o $22 \%$ w porównaniu z metabolizmem gryzoni, co tłumaczy się różnicami w jakości pobieranego pożywienia.

Zmierzono również wielkość termoregulacji chemicznej i stwierdzono, że u N. anomalus jest ona wyższa niż u $N$. fodiens w zakresie temperatur $10-30^{\circ}$ a prawie równa w temperaturze $35^{\circ} \mathrm{C}$. Temperatura neutralna rozciąga się -u obu gatunków w granicach $25-30^{\circ}$ (Tabela 2, Ryc. 1).

Na pođstawie dobowych rytmów zużycia tlenu wykreślono wzorzec aktywności dla obu gatunków rzęsorków (Ryc. 2). $N$. fodiens zarówno jesienią jak i w zimie jest stosunkowo równomiernie aktywny w ciągu calej doby, natomiast wzorzec aktywności $N$. anomalus posiada dwa wyraźne szczyty. Różnice w aktywności zapewne odzwierciedlają różnice $\mathrm{w}$ biologii obu tych gatunków. 